\title{
Ladybird beetles - recent immigrants to Florida (Insecta: Coleoptera: Coccinellidae) ${ }^{1}$
}

Michael C. Thomas and Orland J. Blanchard, Jr. ${ }^{2}$

\section{Introduction}

Since the publication of the Florida beetles checklist (Peck and Thomas 1998), a few ladybird beetles have become established in the state, some well-known and extensively documented (e.g., Harmonia axyridis Pallas and Anovia circumclusa (Gorham)) and some little noticed and previously unreported. It is these latter species that are covered in this publication. All of the listed species are represented by voucher specimens in the Florida State Collection of Arthropods (FSCA). Species previously known from Florida are reported by Frank and Mizell (2012) with emphasis on natural history.

Chilocorus nigrita (Fabricius): This ladybird beetle was first collected in Florida in October 2007, in Miami-Dade County. There are now 15 Florida records for this species, 13 from Miami-Dade County and two from Broward County. It seems to have become established in Florida. It is known from Hawaii in the U.S., but this is the first record of its occurrence in the contiguous 48 states. Chilocorus nigrita is the only medium-sized $(3.2-4.0 \mathrm{~mm})$, non-pubescent, glossy black coccinellid in Florida with a pale head and lateral margins of the pronotum (Fig. 1). Chilocorus nigrita is native to India, but has been distributed throughout the world, mostly in tropical countries, as a biological control agent against various scale insects. Country records are: Agalega (Mauritius), American Samoa, Burma, Brazil, Ghana, Guam, Hawaii, India, Indonesia, Kenya, Madagascar, Malaysia, Marshall Islands,

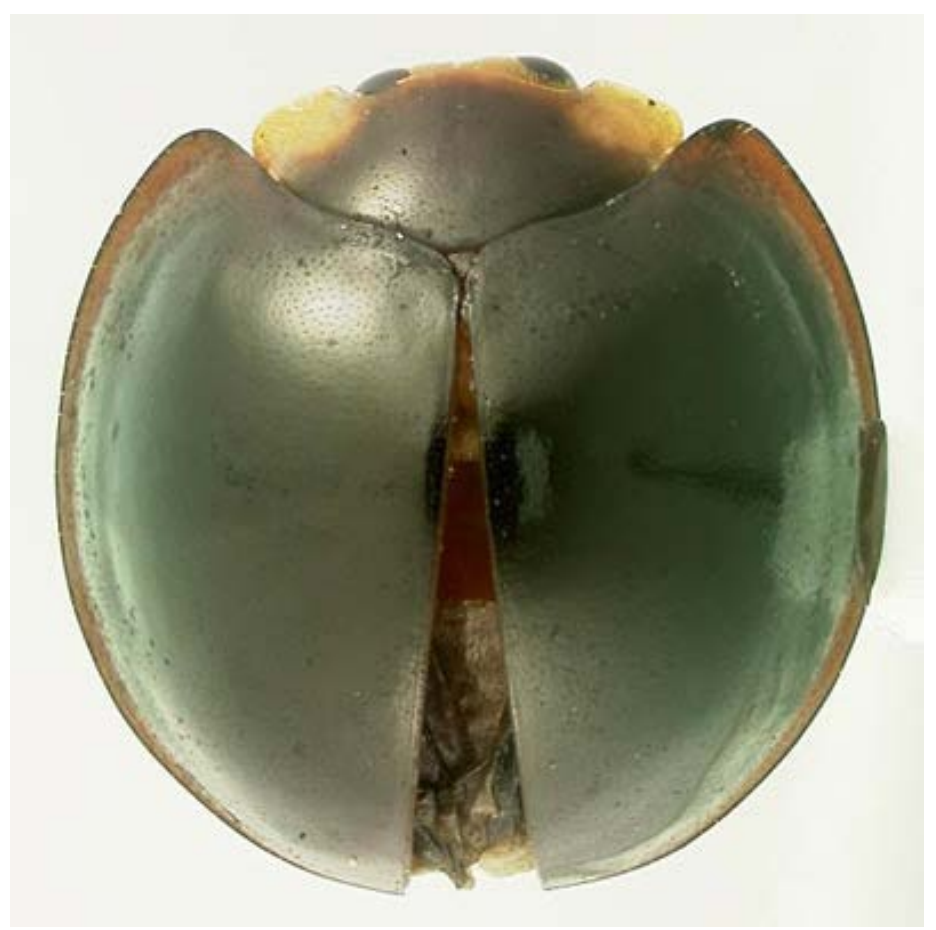

Figure 1. Chilocorus nigrita (Fabricius).

Credits: Michael C. Thomas

New Caledonia, Nepal, Oman, Pakistan, Reunion Island, Seychelles, Solomon Islands, South Africa, Swaziland, Society Islands, Tanzania, Togo, Turkey, and Zimbabwe (Nandwani and Joseph 2003; NBAII 2011; Omkar and Pervez 2003; Poorani 2002). Introductions in Israel and Togo were unsuccessful (Omkar and Pervez 2003). We have examined specimens of this species from Roseau and Marigot Bay, Dominica, collected in June 2010 and

1. This document is EENY575, one of a series of the Entomology and Nematology Department, UF/IFAS Extension. Original publication date October 2013. Visit the EDIS website at http://edis.ifas.ufl.edu.

2. Michael C. Thomas and Orland J. Blanchard, Jr., Florida Department of Agriculture and Consumer Services, Division of Plant Industry, Gainesville, FL 32611. 
September 2011, respectively. These specimens represent a new country record for Dominica and the first record of this species from the Caribbean. Specific Florida records are: Broward (Davie and Hollywood) and Miami-Dade (Bay Harbor Islands, Key Biscayne, Miami, Miami Beach, Miramar, and Sunny Isles). In Florida, it appears to be active year round, with records for: February, April, May, June, July, August, October, and December. Chilocorus nigrita primarily is a predator of scale insects (Hemiptera: Coccidae), but also has been reported to feed on whiteflies, aphids, and psyllids. An extensive host list is given by

NBAII (2011). It is a voracious feeder on scale insects, with each beetle capable of destroying 500 or more scales during its development (Omkar and Pervez 2003).

For this reason, Chilocorus nigrita has been used extensively for many years in classical biological control programs, and is readily vailable for purchase on the internet, where it is promoted for greenhouse use. It is unknown how Chilocorus nigrita arrived in Florida, but it is possible that it was intentionally, if illegally, introduced. Both Federal and State laws require permits for the introduction of exotic organisms into Florida.

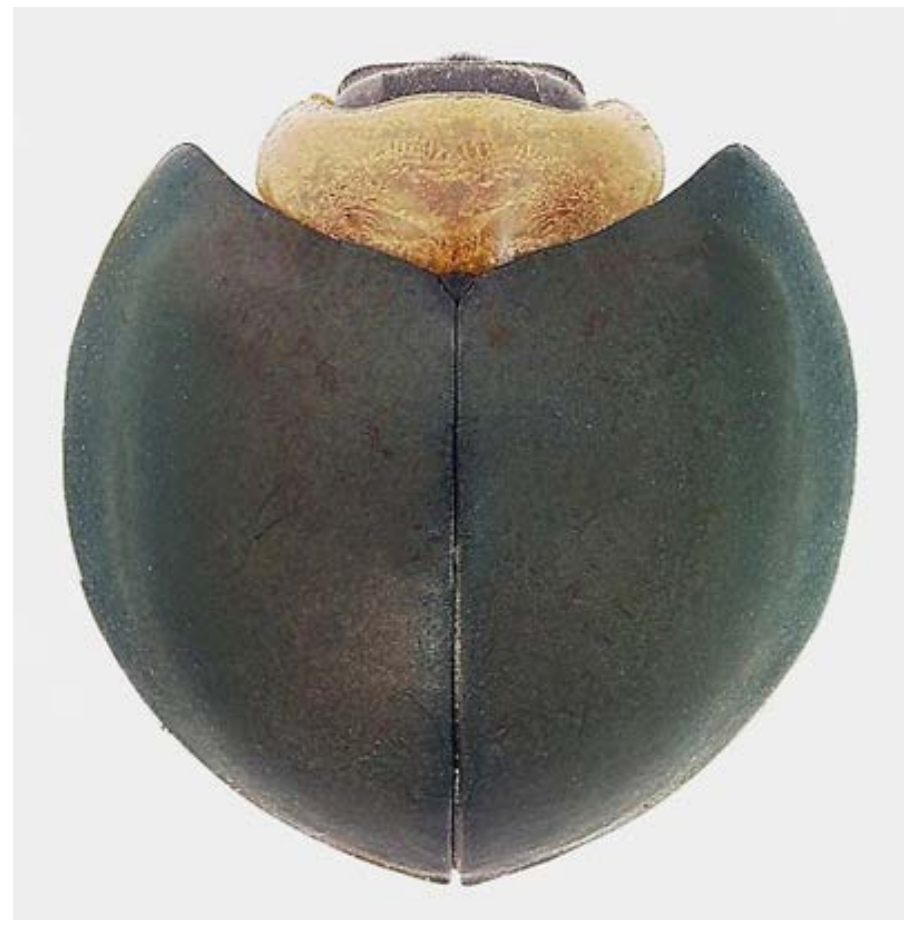

Figure 2. Egius platycephalus Mulsant.

Credits: Michael C. Thomas

Egius platycephalus Mulsant: This is the most recent ladybird beetle immigrant, with a single specimen collected on March 20, 2013 in Davie, Broward County, on the frond of a palmetto (Sabal palmetto (Walter) Lodd. ex Schult. \& Schult.f.). The collector noted (I. Stocks, pers. comm.) that several empty coccinellid pupal exuviae were present on the same frond. Described from Cuba, this species is readily recognizable in the Florida fauna by its non-pubescent dorsal surface, dull black head and elytra, and entirely pale yellow pronotum (Fig. 2). Literature reports suggest that it is primarily a predator of scale insects, but it has been recorded feeding on brown citrus aphid (Toxoptera citricida (Kirkaldy)) in Puerto Rico (Michaud and Browning 1999). It was introduced unsuccessfully into Trinidad in 1943 to combat coconut scale, Aspidiotus destructor Sign (Cock 1985). It was successfully introduced in 1945 into Puerto Rico to combat two bamboo scales (USDA 1946). Later, it was unsuccessfully introduced in 1948 to Bermuda during the biological control campaign against two Bermuda cedar scales (Legner 2013). It was brought into quarantine in Florida in 1988 against black parlatoria scale (Parlatoria ziziphi (Lucas)), but it failed to reproduce and was not released (Frank and McCoy 1993). It is listed in the Bishop Museum database of Hawaiian organisms as being introduced into Hawaii, but it is unclear whether it is established there. There are specimens of this species from Cuba and Puerto Rico in the FSCA.

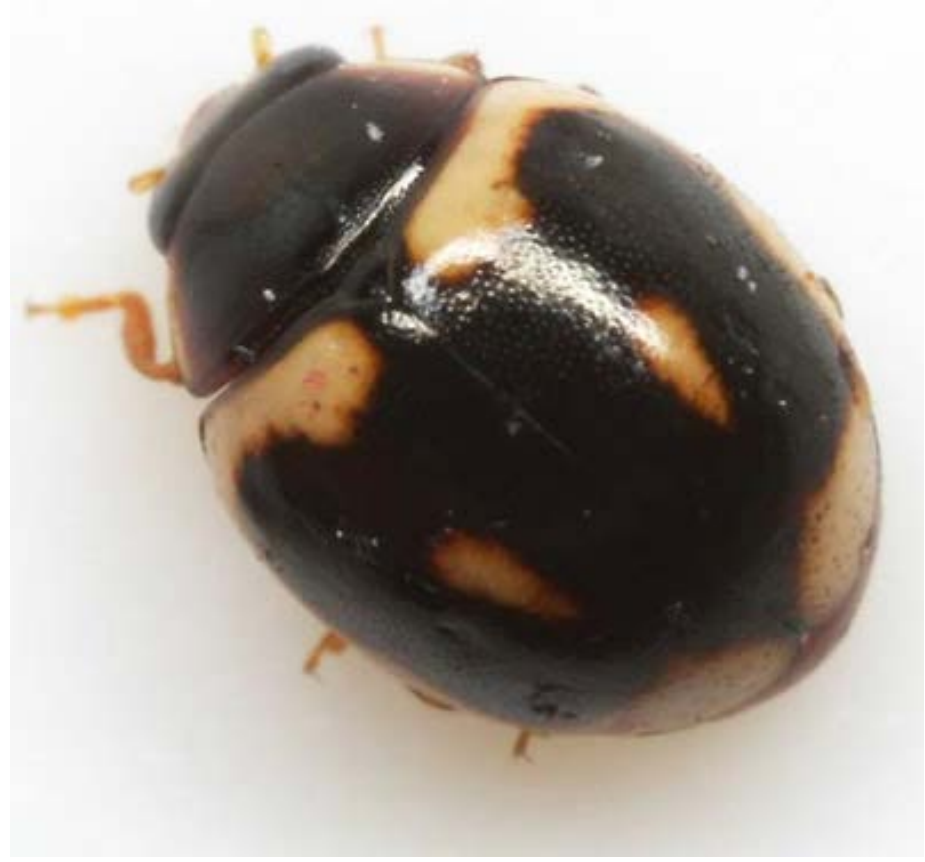

Figure 3. Hyperaspis trifurcata Schaeffer.

Credits: Mike Quinn, BugGuide.net

Hyperaspis trifurcata Schaeffer: This well-known predator of the cochineal insect (Dactylopius coccus Costa) on Opuntia cactus in the desert Southwest has been recorded from Arizona and Texas in the U.S., and in northern Mexico (Gordon 1985). It also occurs in California, as documented 
on BugGuide, and in recent years it has been found in Florida. Hyperaspis is a large genus with 103 species-level taxa in the U.S. alone (Gordon 1985), many of which are very similar externally, and generally require dissection of male genitalia for positive identification. However, Hyperaspis trifurcata has a unique color pattern (Fig. 3); "No other North American species... has a comparable color pattern" (Gordon 1985).

The earliest Florida record we have been able to find is documented on BugGuide by a photograph taken at Apopka, Orange County on October 28, 2006.

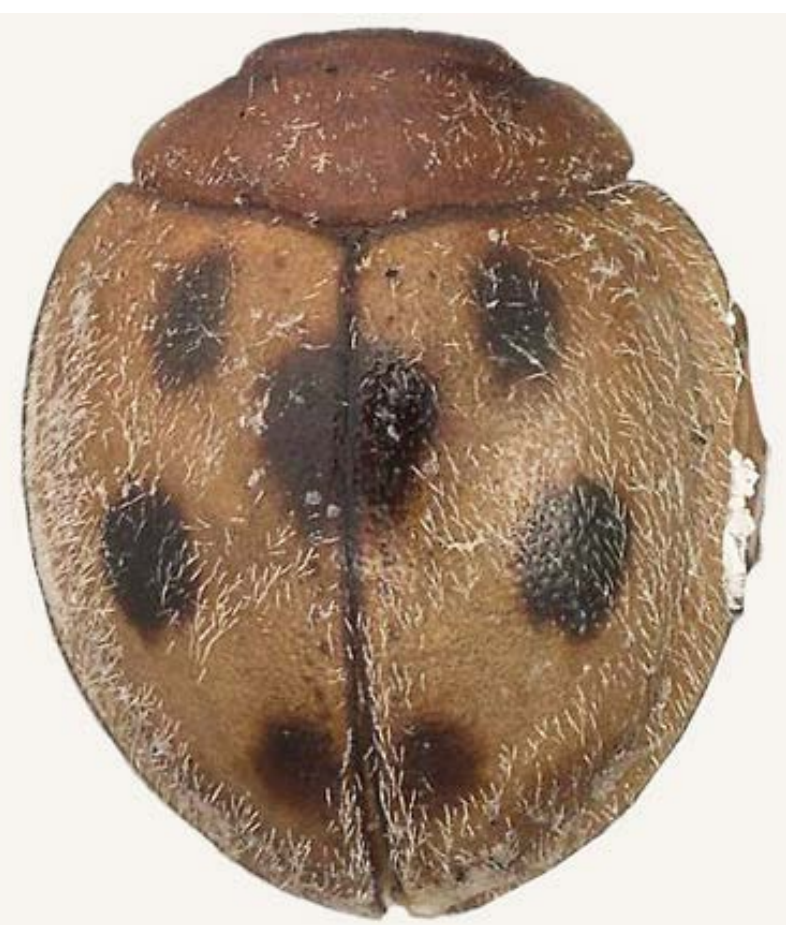

Figure 4. Pharoscymnus flexibilis (Mulsant).

Credits: Michael C. Thomas

Another photograph of a Florida specimen, taken August 19, 2012 at Lakeland, Polk County, was found at Flickr (a photo sharing site). The junior author encountered this species on Opuntia on May 1, 2010, and again on September 8, 2011, in the Ocala National Forest near Lake Delancy, Marion County. Both authors returned to the site in August 2012, but failed to find specimens even though Opuntia heavily infested with the cochineal insect were present. The junior author returned to the same area on September 30, 2012, and again found Hyperaspis trifurcata on the cochineal infested cacti. In addition to the Marion County specimens, there is a series of adults in the FSCA reared from cochineal-infested pads of Opuntia cochenillifera (L.) Mill. collected on August 28, 2012 at Bell, Gilchrist County. At the time the pads were collected, only larvae were present. In Florida, the native cochineal insect is Dactylopius confusus (Cockerell). The introduction of this species to Florida was most likely with infested cacti from the southwestern U.S.

Pharoscymnus flexibilis (Mulsant): The first Florida specimen of this very distinctive Asian ladybird beetle was collected at Miami Beach, Miami-Dade County, September 13, 2011. This is a small, pubescent ladybird beetle (length, $1.8-2.2 \mathrm{~mm}$ ) with distinctive coloration. The ground color of the body is dull brown with dark spots arranged in a characteristic pattern (Fig. 4). The pattern is quite variable (NBAII 2011) and some specimens may be completely brown. The native range of this species is India, Nepal and Pakistan, but was introduced to Brazil (NBAII 2011; Poorani 2002).

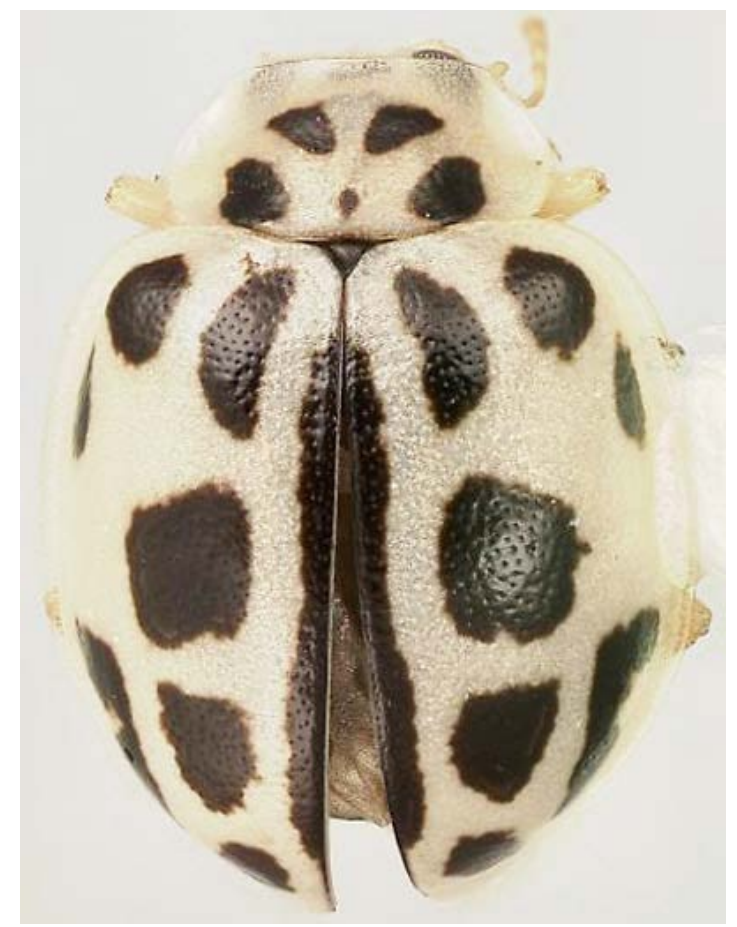

Figure 5. Psyllobora schwarzi Chapin.

Credits: Michael C. Thomas

Pharoscymnus flexibilis is represented by nine Florida records from Broward County (Fort Lauderdale, Pompano Beach) and Miami-Dade County (Golden Beach, Miami, and Miami Beach). It has been collected in the months of: February, March, May, June, July, August, and September. Almost all of the specimens were collected on stickyboard traps. This species feeds primarily on scale insects, but also has been recorded feeding on whiteflies, aphids, and tenuipalpid and tetranychid mites (NBAII 2011). The pathway for its arrival is unknown, but it is likely that it was transported on scale-infested plants from Asia or Brazil. 
Psyllobora schwarzi Chapin: This small West Indian ladybird beetle, which was described from Cuba and the Bahamas (Chapin 1957), was first collected in Florida at Fort Lauderdale, Broward County, February 2012. Since then, it has been collected at three other localities in Miami-Dade County (Key Biscayne, Miami, and North Miami). Collections were in August and October 2012. It appears to be established. All the members of the genus Psyllobora for which biological information is known feed on mildew type fungi (Gordon 1985). Like other Florida members of the genus, Psyllobora schwarzi is pale with a characteristic pattern of dark markings (Fig. 5). Psyllobora schwarzi can be easily distinguished from the other Florida species by the presence of a dark elytral suture. Of the species covered here, this is the only one whose arrival in Florida could have been by natural means, since it is known to occur in nearby Caribbean islands.

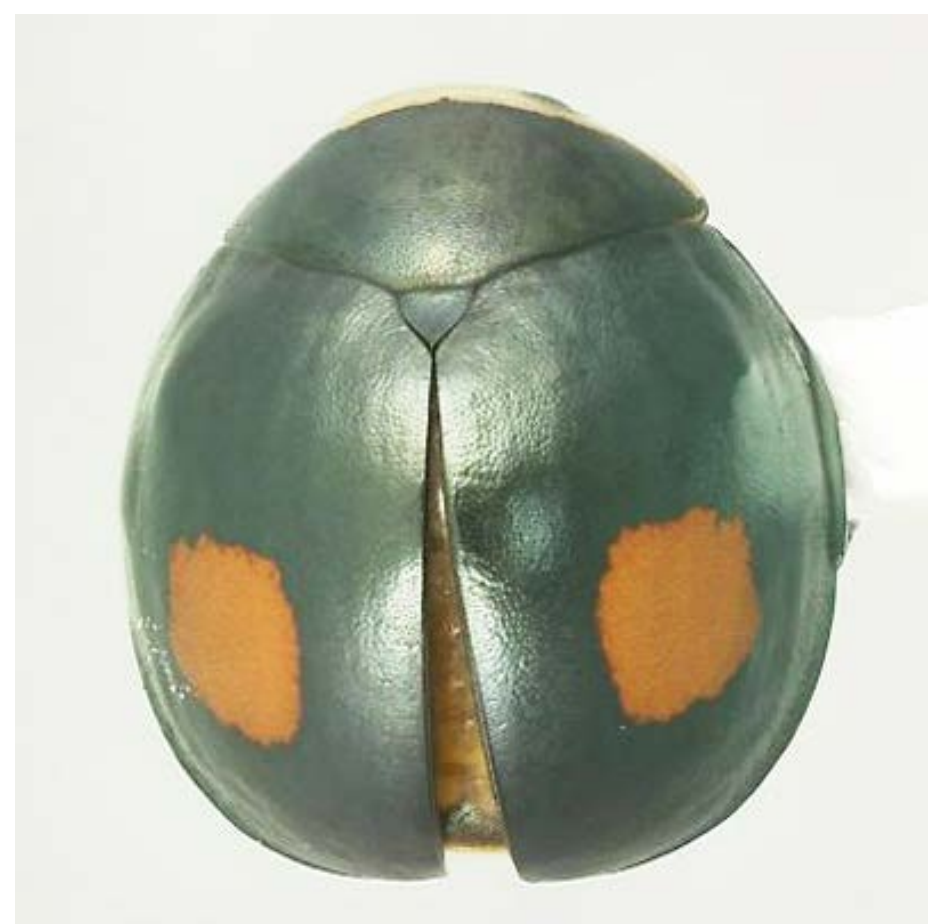

Figure 6. Thalassa montezumae Mulsant.

Credits: Michael C. Thomas

Thalassa montezumae Mulsant: This is another southwestern ladybird beetle that apparently has become established recently in Florida. The first Florida specimens were collected in August 2009 at Homestead, Miami-Dade County. Subsequent records represented in the FSCA are: Broward (Plantation), Hillsborough (Tampa), Martin (Stuart), Miami-Dade (Miami), Palm Beach (Lake Worth). Months collected are January, May, June, and August. Gordon (1985) recorded Thalassa montezumae from Texas and Arizona in the U.S. and Mexico. Milléo et al.(2004) added Guatemala.Thalassa montezumae is strikingly colored and can be confused with no other Florida coccinellid. It is a dull, metallic blue with a yellow or red spot at about the middle of each elytron (Fig. 6). The head and front margin of the pronotum are yellow in males, dark in females. It is 4.5-5.8 mm long. Gordon (1985) reported only one host for this ladybird, the soft scale Toumeyella mirabilis (Cockerell) (Hemiptera: Coccidae). Milléo et al. (2004) did not report any host data for Thalassa montezumae, nor for any of the other five species recognized in the genus. The first Florida specimens were collected on a croton (Codiaeum variegatum (L.) Blume) (Euphorbiaceae) infested with an exotic soft scale, Phalacrococcus howertoni Hodges \& Hodgson (croton scale; Hodges 2008), with which it is relatively commonly found (Catherine Mannion, in litt.). Since the first record of the croton scale in Florida occurred only a year prior to the first collection of Thalassa montezumae (Hodges 2008), it is possible that the two arrived concurrently.

\section{Acknowledgements}

We thank all of the Division of Plant Industry and Cooperative Agricultural Pest Survey inspectors who collected many of the specimens reported above, but especially Olga Garcia, Michelle DaCosta and Julio Garcia. Dr. Catherine Mannion and Holly Glenn, of the University of Florida, submitted the first specimens of Thalassa montezumae and supplied biological information. Dr. Ian Stocks helped out with scale insect taxonomy

\section{Selected References}

Chapin EA 1957. Records of coccinellid beetles from the Cayman Islands, with descriptions of new species from the West Indies. Entomologist's Monthly Magazine 93: 89-91.

Cock MJW 1985. A review of biological control of pests in the Commonwealth Caribbean and Bermuda up to1982. Commonwealth Institute of Biological Control, Technical Communication 9; i-xii, 1-218.

Frank JH, McCoy ED. 1993. Introduction to the behavioral ecology of introduction: the introduction of insects into Florida. Florida Entomologist 76: 1-53.

Frank JH, Mizell RF III. 2012. Ladybirds, lady beetles, ladybugs [of Florida]. Featured Creatures. EENY 170.

Gordon RD 1985. The Coccinellidae (Coleoptera) of America north of Mexico. Journal of the New York Entomological Society 93: 1-912. 
Hodges G. 2008. Pest Alert: A new exotic soft scale insect on croton in South Florida (Hemiptera: Coccoidea: Coccidae). (20 September 2013).

Legner EF 2013. Bermuda cedar scales, Carulaspis minima (Targioni-Tozzetti) \& Lepidosaphes newsteadi (Sulc.)-

Diaspididae. (20 September 2013).

Milléo J, Massutti de Almeida L, and Gordon RD. 2004. South American Coccinellidae (Coleoptera). Part X: A systematic revision of Thalassa Mulsant (Hyperaspidinae). Revista Brasileira de Entomologia 48: 395-400.

NBAII. 2011. Chilocorus nigrita (Fabricius). National Bureau of Agriculturally Important Insects. Bangalore, India. (20 September 2013).

NBAII. 2011. Pharoscymnus flexibilis (Mulsant). National Bureau of Agriculturally Important Insects. Bangalore, India. (20 September 2013).

Peck SB, Thomas MC. 1998. A distributional checklist of the beetles (Coleoptera) of Florida. Arthropods of Florida and Neighboring Land Areas 16: i-viii + 1-180.

Poorani J. 2002. An annotated checklist of the Coccinellidae (Coleoptera) (excluding Epilachninae) of the Indian subregion. Oriental Insects 36: 307-383.

Omkar and Pervez A. 2003. Ecology and biocontrol potential of a scale-predator, Chilocorus nigritus.

Biocontrol Science and Technology 13: 379-390.

Michaud JP and Browning HW. 1999. Seasonal abundance of the brown citrus aphid, Toxoptera citricida, (Homoptera: Aphididae) and its natural enemies in Puerto Rico. Florida Entomologist 82:

424-447.

Nandwani D, and Joseph J . 2003. Biological control of insect and plant pests in the Marshall Islands. Micronesica Supplement 7: 125-132.

USDA. 1946. Report on the Agricultural Experiment Stations, 1945. U.S. Department of Agriculture, Office of Experiment Stations. Washington, D. C. 172 p.

Wolcott GN. 1950. The insects of Puerto Rico. Journal of Agriculture of the University of Puerto Rico 32: 225-416. 